\section{Pengaruh Sosial Media Marketing Dan Electronic Word Of Mouth Terhadap Minat Beli Pada Produk Sepatu Converse Pada Mahasiswa FEB Universitas Prof Dr Hamka}

\author{
Radifa Witsqa Muhammad, Eti Rochaeti dan Edi Setiawan \\ Program Studi Manajemen, Fakultas Ekonomi dan Bisnis \\ Universitas Prof Dr Hamka \\ E-Mail: radifawitsqaam@gmail.com, etinulisbuku@gmail.com, \\ edisetiawan@uhamka.ac.id
}

\section{ABSTRACT}

This study aims to determine the effect of Social Media Marketing and Electronic Word of Mouth on Buying Intention to Buy Converse Shoes in Students of Prof. DR. HAMKA. The theory used in this research is Marketing Management theory which is related to Social Media Marketing and e-word of mouth. The research method used is a survey method with data collection techniques through a questionnaire, while the type of research is descriptive quantitative. The sample in this study amounted to 155 respondents. To test the hypothesis, multiple linear regression analysis was used by performing test $T$ and test F.Research using SPSS 20.0 software suggests that 1). Social Media Marketing has a positive and partially significant effect on Buying Interest. 2). E-Word Of Mouth has a positive and partially significant effect on Buying Interest. 3). Social Media Marketing and E-Word Of Mouth simultaneously influence Buying Interest. Because the $t$ value of Social Media Marketing $(5,923)$ is greater than $t$ table $(1,975)$ and $e$-word of mouth $(4,480)$ is greater than $t$ table $(1,975)$ and $f$ count of the independent variable $(97,157)$ is greater than $f$ table $(3,06)$. The value of the coefficient of determination (Adjusted $R^{2}$ ) obtained a value of $55.5 \%$ indicative that contributions to impact Social Media Marketing and e-word of mouth together can affect purchase interest. The remaining $44.5 \%$ is is affected by other factors beyond research.

Keywords: sosial media marketing, electronic word of mouth and the interest of buying
Customer Buying

Decision and

Promotional Mix

MARTT 2021

Accepted: JUNI 2021

\title{
ABSTRAK
}

Penelitian ini bertujuan untuk mengetahui pengaruh Sosial Media Marketing Dan Electronic Word Of Mouth Terhadap Minat Beli Produk Sepatu Converse Pada Mahasiswa Feb Universitas Prof. DR. HAMKA. Teori yang digunakan dalam penelitian ini yaitu teori Manajemen Pemasaran yang berhubungan dengan sosial media marketing dan e-word of mouth. Metode penelitian yang digunakan yaitu metode survey dengan teknik pengumpulan data melalui kuesioner, sedangkan jenis penelitiannya deskriptif kuantitatif. Sampel pada penelitian ini berjumlah 155 responden. Untuk menguji hipotesis digunakan analisis regresi linier berganda dengan melakukan uji $\mathrm{T}$ dan uji $\mathrm{F}$. Hasil penelitian dengan menggunakan software SPSS 20.0 menunjukan bahwa 1). Sosial Media Marketing berpengaruh positif dan signifikan secara parsial terhadap Minat Beli. 2). EWord Of Mouth berpengaruh positif dan signifikan secara parsial terhadap Minat Beli. 3).Sosial Media Marketing dan E-Word Of Mouth berpengaruh secara simultan terhadap Minat Beli. Karena nilai t hitung sosial media marketing $(5,923)$ lebih besar dari t tabel $(1,975)$ dan e-word of mouth $(4,480)$ lebih besar dari t tabel $(1,975)$ dan $\mathrm{f}$ hitung variabel independen $(97,157)$ lebih besar dari f tabel $(3,06)$. Nilai koefisien determinasi (Adjusted $R)^{2}$ diperoleh nilai sebesar 55,5\% menunjukan bahwa kontribusi pengaruh sosial media marketing dan e-word of mouth secara bersama-sama dapat mempengaruhi minat beli.

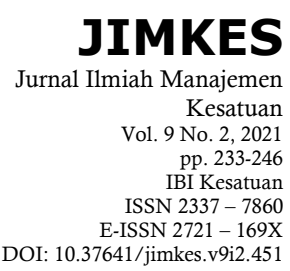


Customer Buying

Decision and

Promotional Mix

234

Sedangkan sisanya sebesar 44,5\% dipengaruhi oleh faktor-faktor lain diluar penelitian.

Kata Kunci: Sosial Media Marketing, Electronic Word Of Mouth dan Minat Beli

\section{PENDAHULUAN}

Di era globalisasi dan ekonomi bebas sekarang ini, para pelaku bisnis tidak hanya beroperasi dalam negeri namun sudah memasuki perekonomian global. Perubahan dan perkembangan perekonomian global terus bergerak dalam jangka waktu yang sangat cepat. Produsen dituntut untuk lebih peka, kritis dan reaktif terhadap perubahan yang ada, baik politik, social budaya, maupun ekonomi. Strategi merupakan formula yang memiliki basis sangat luas mengenai bagaimana bisnis dijalankan untuk bersaing guna mencapai suatu tujuan. Disisi lain perkembangan teknologi yang semakin cepat dan canggih pun menjadi tantangan dan mendorong pelaku bisnis untuk mampu menguasai teknologi, di masa sekarang kita semua pasti tahu bahwa kemajuan teknologi sangat pesat, kemajuan ini tentunya membawa banyak perubaham terhadap kebuadayaan di Indonesia.

Di dalam dunia pemasaran seperti halnya sebuah kompetisi, setiap perusahaan berlomba dan bersaing untuk memasarkan produknya. Hal ini menjadi perhatian berbagai macam industri, salah satunya adalah industry sepatu. Meningkatnya kebutuhan dan kesadaran konsumen dalam memilih sepatu sesuai dengan perkembangan style dan kebutuhan membuat perusahaan yang membuat merk Converse, Adidas, Nike, Bata dan Reebook selalu bersaing untuk mendapatkan selera konsumen agar membeli produk mereka.

Tabel 1. Daftar Penjualan Sepatu yang Masuk Top Brand Sepatu Casual

\begin{tabular}{|l|l|l|l|l|l|l|l|l|}
\hline \multirow{2}{*}{ Merek } & \multicolumn{2}{|c|}{2016} & \multicolumn{2}{c|}{2017} & \multicolumn{2}{c|}{2018} & \multicolumn{2}{c|}{2019} \\
\cline { 2 - 9 } & TBI & TOP & TBI & TOP & TBI & TOP & TBI & TOP \\
\hline Nike & $14,50 \%$ & TOP & $35,20 \%$ & TOP & $31,6 \%$ & TOP & $12,2 \%$ & - \\
\hline Adidas & $7,00 \%$ & - & $6,00 \%$ & - & $9,00 \%$ & - & $11,2 \%$ & - \\
\hline $\begin{array}{l}\text { Converse } \\
\text { All Star }\end{array}$ & $6,60 \%$ & - & $5,00 \%$ & - & - & - & $6,3 \%$ & - \\
\hline Bata & $5,20 \%$ & - & $4,10 \%$ & - & $7,00 \%$ & - & $19,3 \%$ & TOP \\
\hline Tomkins & $5,00 \%$ & - & $3,80 \%$ & - & - & - & - & - \\
\hline Reebok & $3,90 \%$ & - & - & - & - & - & - & - \\
\hline
\end{tabular}

Sumber: Topbrand-award.com

Dari tahun 2016-2019 dapat dilihat pada Tabel bahwa sepatu Convesrre All Star tidak pernah menduduki posisi sebagai top brand penjualan sepatu casual, Seiring berjalannya waktu peningkatan penjualan di Indonesia kurang terlihat adanya pertumbuhan. Hal ini terjadi ketika munculnya produk palsu, memanfaatkan dari segi harga yang lebih terjangkau serta segi efektivitas sepatu Converse dapat dipakai baik oleh wanita maupun pria dan dapat dipadukan dengan berbagai gaya busana.

Social media telah dijadikan sebagai salah satu sarana yang digunakan untuk melakukan pemasaran produk atau yang biasa juga disebut dengan social media marketing. Social Media Marketing adalah sebuah proses yang mendorong setiap individu untuk melakukan promosi melalui situs web, produk, atau layanan mereka melalui saluran sosial online dan untuk berkomunikasi dengan memanfaatkan sebuah komunitas yang jauh lebih besar yang memiliki kemungkinan lebih besar untuk melakukan pemasaran daripada melalui saluran periklanan tradisional. Konsep produk berpendapat bahwa konsumen menyukai produk yang menawarkan kualitas, kinerja, atau fitur inovatif terbaik. Suatu produk baru tidak akan sukses jika tidak didukung oleh harga, distribusi, iklan, dan penjualan yang tepat (Kotler, 2012:19). 
E-WOM melalui media sosial mampu membuat konsumen tidak hanya mendapatkan informasi namun juga bisa berkomunikasi dan bertukar informasi mengenai produk dan jasa terkait dari orang-orang yang mereka kenal, namun juga dari sekelompok orang yang berbeda area geografisnya yang memiliki pengalaman terhadap produk atau jasa yang dimaksud (Christy dalam Tommi Wijaya, 2014:13).

Minat beli dipengaruhi oleh media sosial yang dilakukan melalui persepsi konsumen terhadap produk Minat beli konsumen pada dasarnya merupakan faktor pendorong dalam pengambilaan keputusan pembelian terhadap suatu produk, minat beli konsumen merupakan evaluasi purna beli atau hasil evaluasi setelah membandingkan apa yang dirasakan dengan harapannya (Yamit 2001:77)

Untuk memperkuat penelitian ini, peneliti merujuk pada beberapa penelitianpeneltian terdahulu. Penelitian Akmal Ghani Dwianto, Mohammad Iqbal dan Rizal Alfisyahr (2018), Meatry Kurniasari dan Agung Budiatmo (2018), Gevi Tonida Resky (2016), Muhammad Aries, Sunarti dan M. Kholid Mawardi (2018). Menghasilkan bahwa sosial media marketing dan e-wom berpengaruh positif dan signifikan terhadap minat beli.

Hal ini berbeda dengan penelitian Dewi Kurniawati dan Nugraha Arifin (2015), Indra Ariesta dan Dinda Amanda Zuliestiana (2019), Rosmaya Adriyati dan Farida Indriani (2017). Menghasilkan bahwa sosial media marketing dan e-wom berpengaruh negatif terhadap minat beli.

Menurut Chris Hauer (2010:263) terdapat indikator-indikator dalam penggunaan sosial media, yaitu :

1. Context: "How we frame our stories" adalah bagaimana kita membentuk sebuah cerita atau pesan (informasi) seperti bentuk dari sebuah pesan itu sendiri, penggunaan bahasa maupun isi dari pesan tersebut.

2. Communication: "The practice of sharing our sharing story as well as listening, responding, growing." Adalah bagaimana berbagi cerita atau pesan (informasi) sebaik kita mendengar, merespon dan tumbuh dengan berbagai cara yang membuat pengguna merasa nyaman dan pesan tersampaikan dengan baik.

3. Collaboration: "Working together to make things better and more efficient and effective." Adalah bagaimana bekerja sama untuk membuat segala hal untuk menjadi lebih baik. Yaitu dengan kerja sama antara sebuah akun atau perusahaan dengan penggunanya di media sosial untuk membuat hal baik lebih efektif dan efisien

4. Connection: "The relationships we forge and maintain." Adalah bagaimana memelihara hubungan yang telah terbina, bisa dengan melakukan sesuatu yang bersifat berkelanjutan sehingga pengguna lebih dekat dengan perusahaan pengguna media sosial.

Menurut Goyette et al.,(2010:11), dalam mengukur pengaruh Electronic Word of Mouth (e-WOM) menggunakan dimensi sebagai berikut

1. Intensity (Intensitas)

eWOM adalah banyaknya pendapat yang ditulis konsumen dalam sebuah situs jejaring sosial Goyette, (2010:11) Intensity terdiri dari indicator sebagai berikut :

1) Mengakses informasi melalu website

2) Mengakses informasi melalui sosial media

3) Interaksi dengan konsumen lain melalui sosial media

2. Valence of opinion

Merupakan pendapat konsumen baik positif atau negative mengenai produk, jasa dan brand. Valence of opinion memiliki dua sifat yaitu positif dan negatif. Valence of opinion meliputi:

1) Penilaian terhadap testimoni positif yang diberikan oleh konsumen 2)Penilaian terhadap testimoni negative yang diberikan oleh konsumen 3)Kesediaan merekomendasikan kepada 
Customer Buying

Decision and

Promotional Mix

236 konsumen lain 4)Keinginan untuk mendorong konsumen lain untuk menggunakan suatu produk

3. Content

Merupakan isi dari informasi situs jejaring sosial berkaitan dengan produk dan jasa. Indicator dari konten meliputi:

1) Desain web site

2) Variasi produk

3) Pelayanan konsumen

4) Penampilan Produk

5) Spesifikasi Produk

6) Informasi Harga

Menurut Ferdinand (2002:129), Dimensi dan Indikator minat beli dapat diidentifikasikan melalui dimensi-dimensi sebagai berikut :

1. Minat transaksional, yaitu kecenderungan sesorang untuk membeli produk.

2. Minat referensial, yaitu kecenderungan seseorang untuk mereferensikan produkn kepada orang lain

3. Minat preferensial, yaitu minat yang menggambarkan perilaku dari seseorang yang memiliki preferensi utama pada produk tersebut. Preferensi ini hanya bisa diganti jika terjadi sesuatu dengan produk preferensinya.

Minat eksploratif, minat ini menggambarkan perilaku seseorang yang selalu mencari informasi mengenai produk yang diminatinya dan mencari infromasi untuk mendukung sifat- sifat positif dari produk tersebut.

\section{METODE PENELITIAN}

Penelitian yang dilakukan adalah dengan menggunakan metode survey dengan analisis data kuantitatif, yaitu menggambarkan dan menganalisis Pengaruh Sosial Media Marketing dan Electronic Word Of Mouth terhadap Minat Beli Produk Sepatu Converse Mahasiswa Feb Universitas Prof Dr Hamka.

Metode penelitian survey adalah metode penelitian kuantitatif yang digunakan untuk mendapatkan data yang terjadi pada masa lampau atau saat ini, tentang keyakinan, pendapat karakteristik, perilaku, hubungan variabel dan untuk menguji beberapa hipotesis tentang variabel sosiologis dan psikologis dari sampel yang diambil dari populasi tertentu, Teknik pengumpulan data dengan pengamatan (wawancara atau kuesioner) yang tidak mendalam dan hasil penelitian cenderung untuk digeneralisasikan (Sugiyono, 2015:81)

Variabel yang digunakan dalam penelitian ini adalah variabel tidak terikat (X1) adalah Sosial Media Marketing dan (X2) adalah E-Wom terhadap variabel terikat (Y) adalah Minat Beli. Data dalam penelitian ini diperoleh dari Mahasiswa Feb Universitas Prof Dr Hamka.

Hipotesis penelitian dapat di artikan sebagai jawaban yang bersifat sementara tehadap masalah penelitian, sampai terbukti melalui data yang terkumpul dan harus di uji secara empiris. Berdasarkan uraian kerangka pemikiran di atas, maka hipotesis penelitian adalah sebagai berikut :

H1 :Diduga Sosial Media Marketing berpengaruh terhadap Minat Beli Produk Sepatu Converse

H2 :Diduga E-Word Of Mouth berpengaruh terhadap Minat Beli Produk Sepatu Converse

H3 :Diduga Social Media Marketing dan E-Word Of Mouth Berpengaruh Terhadap Minat Beli Produk Sepatu Converse 


\section{Profil Responden}

Identitas responden yang dapat diungkap dalam penelitian ini meliputi usia, jenis kelamin, pendidikan terakhir dari konsumen Converse. Hal tersebut dimaksudkan untuk menjelaskan latar belakang responden yang menjadi sampel dalam penelitian ini. Pada penelitian ini terdapat 155 responden yang diambil sebagai sampel. Data mengenai identitas responden dapat dilihat pada tabel berikut ini:

1. Usia

Untuk melihat responden dari usia dikelompokan menjadi 2 kelompok, yaitu $<19$ tahun, $>20$ tahun. Untuk lebih jelasnya dapat dilihat pada tabel berikut ini:

\section{Usia Responden}

\begin{tabular}{|c|c|c|c}
\hline No & Usia & Jumlah Responden & Persentase (\%) \\
\hline 1. & $<19$ tahun & 8 & 5,2 \\
\hline 2. & $>20$ tahun & 147 & 94,8 \\
\hline & Jumlah & 155 & 100 \\
\hline
\end{tabular}

Dari tabel diatas, menunjukkan bahwa usia responden dalam penelitian ini adalah responden yang berusia antara $<19$ tahun sebanyak 8 orang atau 5,2\%, dan responden berusia antara $>20$ tahun sebanyak 147 orang atau 94,8\%. Dapat di simpulkan bahwa mayoritas responden dalam penelitian ini adalah responden berusia antara $>20$ tahun sebanyak 147 orang atau 94,8\%, dari total keseluruhan responden berjumlah 155 orang.

2. Jenis Kelamin

Untuk melihat karakteristik responden dari jenis kelamin dikelompokan menjadi 2 kelompok, yaitu laki-laki dan perempuan. Untuk lebih jelasnya dapat dilihat pada tabel berikut ini

\begin{tabular}{|c|c|c|c|}
\hline \multicolumn{5}{|c|}{ Jenis Kelamin Responden } \\
\hline No & Pendidikan & Jumlah Responden & Persentase (\%) \\
\hline 1. & SMA & 90 & 58,1 \\
\hline 2. & SMK & 39 & 25,2 \\
\hline 3. & MA & 20 & 12,9 \\
\hline 4 & PESANTREN & 6 & 3,9 \\
\hline \multicolumn{2}{|l|}{ Jumlah } & 155 & 100 \\
\hline
\end{tabular}

\section{Sumber: Data Kuesioner 2020}

Dari tabel diatas, menunjukan bahwa jenis kelamin responden dalam penelitian ini adalah responden yang berjenis kelamin laki-laki sebanyak 93 orang atau $60 \%$ dan responden perempuan sebanyak 62 orang atau 40\% Dapat disimpulkan bahwa mayoritas responden dalam penelitian ini adalah berjenis kelamin Laki-Laki sebanyak 93 orang atau $60 \%$, dari total keseluruhan responden berjumlah 155 orang.

3. Pendidikan Terakhir

Untuk melihat karakteristik responden dari pendidikan terakhir dikelompokan menjadi 4 kelompok, yaitu SMA, SMK, MA dan PESANTREN. Untuk lebih jelasnya dapat dilihat pada tabel berikut ini :

\begin{tabular}{|c|c|c|c|}
\hline \multicolumn{4}{|c|}{ Pendidikan Terakhir Responden } \\
\hline No & Pendidikan & Jumlah Responden & Persentase (\%) \\
\hline 1. & SMA & 90 & 58,1 \\
\hline 2. & SMK & 39 & 25,2 \\
\hline 3. & MA & 20 & 12,9 \\
\hline 4 & PESANTREN & 6 & 3,9 \\
\hline & Jumlah & 155 & 100 \\
\hline
\end{tabular}

Customer Buying

Decision and

Promotional Mix 
Customer Buying

Decision and

Promotional Mix

238
Sumber: Data Kuesioner 2020

Dari tabel diatas, menunjukan bahwa pendidikan terakhir dalam penelitian ini adalah responden yang berpendidikan SMA sebanyak 90 orang atau 58,1\%, responden berpendidikan terakhir SMK sebanyak 39 orang atau 25,2\%, responden berpendidikan terakhir MA sebanyak 20 orang atau $12,9 \%$ dan responden berpendidikan terakhir PESANTREN sebanyak 6 orang atau 3,9 \%. Dapat disimpulkan bahwa mayoritas responden dalam penelitian ini adalah responden yang berpendidikan terakhir SMA sebanyak 90 orang atau $58,1 \%$, dari total keseluruhan responden yang berjumlah 155 orang.

4. Model Sepatu Responden

Untuk melihat karakteristik responden dari model sepati dikelompokan menjadi 4 kelompok, yaitu converse chuck taylor all star, converse one star, converse jack purcell dan converse special edition. Untuk lebih jelasnya dapat dilihat pada tabel berikut ini

Model Sepatu Responden

\begin{tabular}{|c|c|c|c|}
\hline No & Model Sepatu & Jumlah Responden & Persentase (\%) \\
\hline 1. & Converse Chuck Taylor All Star & 76 & 49 \\
\hline 2. & Converse One Star & 40 & 25,8 \\
\hline 3. & Converse Jack Purcell & 17 & 11 \\
\hline 4 & Converse Spesial Edition & 22 & 14,2 \\
\hline & Jumlah & 155 & 100 \\
\hline
\end{tabular}

\section{Uji Validitas}

Untuk uji validitas dengan 155 responden maka nilai signifikansinya adalah 0,157 , Hasil Uji Validitas menunjukkan bahwa variabel Sosial Media Marekting memiliki nilai rhitung lebih besar dari rtabel 0.157 sehingga dapat disimpulkan bahwa ke 10 butir pertanyaan Social Media Marketing tersebut valid. Hasil uji validitas untuk pertanyaan variabel instagram e-word of mouth menunjukkan bahwa nilai rhitung lebih besar dari rtabel 0.157 sehingga dapat disimpulkan bahwa ke 10 butir pertanyaan electronic word of mouth tersebut valid.

Hasil uji validitas untuk pertanyaan variabel minat beli menunjukka bahwa nilai rhitung lebih besar dari rtabel 0.157 sehingga dapat disimpulkan bahwa ke 10 butir pertanyaan keputusan pembelian tersebut valid. Jadi, dapat disimpulkan bahwa dalam penelitian ini seluruh instrumen yang digunakan valid. Sehingga untuk proses pengujian selanjutnya, seluruh instrumen tersebut dapat diikutsertakan.

\section{Uji Reliabilitas}

Hasil uji reliabilitas yang didapat dari butir-butir pertanyaan kuesioner Sosial Media Marketing, E-Wom, Dan Minat Beli. dapat dilihat pada tabel berikut:

Uji Reliabilitas Variabel Sosial Media Marketing, Electronic Word Of Mouth dan Minat Beli

\begin{tabular}{|c|c|c|c|}
\hline Variabel & $\begin{array}{c}\text { Cronbach's } \\
\text { Alpaha }\end{array}$ & $\begin{array}{c}\text { Standar } \\
\text { Reabilitas }\end{array}$ & Keterangan \\
\hline Sosial Media Marketing & 0.668 & 0.60 & Reliabel \\
\hline E-Word Of Mouth & 0.728 & 0.60 & Reliabel \\
\hline Minat Beli & 0.658 & 0.60 & Reliabel \\
\hline
\end{tabular}

Sumber: Output SPSS Statistics 20.0

Hasil nilai cronbach's alpha variabel kuesioner Sosial Media Marketing, Electronic Word Of Mouth dan Minat Beli adalah $>0.60$ sehingga indikator atau kuesioner dari variabel tersebut reliabel atau dapat dipercaya sebagai alat ukur variabel.

Analisis Statistik Deskriptif

1. Secara keseluruhan tanggapan responden terhadap variabel sosial media marketing 
adalah baik $(3,90 ; 5) \times 100 \%=78 \%$, karena berada diantara interval $(68.01-84,00)$.

2. Secara keseluruhan tanggapan responden terhadap variabel electronic word of mouth adalah baik $(4,11 ; 5) \times 100 \%=52,2 \%$, karena berada diantara interval $(68.01-$ $84,00)$.

3. Secara keseluruhan tanggapan responden terhadap variabel Minat Beli Pada Produk Sepatu Converse adalah baik $(4,11 ; 5) \times 100 \%=52,2 \%$, karena berada diantara interval $(68.01-84,00)$.

\section{Model Regresi Linear Berganda}

Hasil persamaan regresi linier berganda dalam penelitian ini diuraikan dalam bentuk sebagai berikut:

\section{Hasil Regresi Linier Berganda Coefficients $^{\text {a }}$}

\begin{tabular}{|c|c|c|c|c|c|c|c|}
\hline \multirow{2}{*}{ Model } & \multicolumn{2}{|c|}{$\begin{array}{c}\text { Unstandardized } \\
\text { Coefficients }\end{array}$} & \multirow{2}{*}{$\begin{array}{c}\begin{array}{c}\text { Standardized } \\
\text { Coefficients }\end{array} \\
\text { Beta }\end{array}$} & \multirow{2}{*}{$\mathrm{T}$} & \multirow{2}{*}{ Sig. } & \multicolumn{2}{|c|}{ Collinearity Statistics } \\
\hline & B & $\begin{array}{l}\text { Std. } \\
\text { Error }\end{array}$ & & & & Tolerance & VIF \\
\hline $\begin{array}{l}\text { (Constant) } \\
\text { sosial media } \\
\text { marketing }\end{array}$ & $\begin{array}{r}9,527 \\
, 443\end{array}$ & $\begin{array}{r}2,134 \\
, 075\end{array}$ & ,459 & $\begin{array}{l}4,465 \\
5,923\end{array}$ &, 000 & ,481 & 2,080 \\
\hline $\begin{array}{l}\text { e word of } \\
\text { mouth }\end{array}$ & ,313 & ,070 & ,347 & 4,480 &, 000 & ,481 & 2,080 \\
\hline
\end{tabular}

a. Dependent Variable: Y

Sumber: Output SPSS 20.0

$\dot{Y}=9.527+0.443 \mathrm{X} 1+0.313 \mathrm{X} 2$

1. Hasil regresi linier berganda memperlihatkan nilai konstanta sebesar 9.527 secara sistematis menyatakan bahwa jika nilai variabel X1 (sosial media marketing) dan X2 (eword of mouth) sama dengan nol maka nilai skor Y (minat beli) adalah 9.527

2. Koefisien regresi variabel X1 (sosial media marketing) sebesar 0.443 , yang artinya setiap $\mathrm{X} 1$ (sosial media marketing) meningkat sebesar 1 skor dengan asumsi variabel $\mathrm{X} 2$ (eword of mouth) konstan akan menyebabkan kenaikan skor minat beli sebesar 0.443 dan sebaliknya.

3. Koefisien regresi variabel $\mathrm{X}_{2}$ (e-word of mouth) sebesar 0.313 , artinya setiap $\mathrm{X}_{2}$ (eword of mouth) meningkat sebesar 1 skor dengan variabel X1 (sosial media marketing) konstan akan menyebabkan kenaikan skor minat beli sebesar 0.313 dan sebaliknya.

\section{Uji Normalitas}

Dalam penelitian ini pengujian normalitas data menggunakan grafik Normal P-P Plot of Regression Standardized Residual. Hasil grafik normal p-plot pada penelitian ini sebagai berikut
Customer Buying

Decision and

Promotional Mix

239 
Customer Buying

Decision and

Promotional Mix

240
Berdasarkan gambar di atas, pola menunjukkan penyebaran titik-titik berada di sekitar garis diagonal dan mengikuti arah garis diagonal sehingga dapat diinterpretasikan bahwa model regresi memenuhi asumsi normalitas. Hasil uji normalitas dengan grafik Normal Probability Plot tersebut perlu didukung melalui uji normalitas dengan uji Kolmogorov-Smirnov yang disajikan pada tabel berikut ini.

One-Sample Kolmogorov-Smirnov Test

\begin{tabular}{|ll|r|}
\hline & & \multicolumn{2}{|c|}{$\begin{array}{c}\text { Unstandardize } \\
\text { d Residual }\end{array}$} \\
\hline N Normal Parameters ${ }^{\mathrm{a}, \mathrm{b}}$ & Mean & 155 \\
& Std. Deviation & $0 \mathrm{E}-7$ \\
Most Extreme & Absolute & 2.64349249 \\
Differences & Positive & .052 \\
& Negative & .029 \\
Kolmogorov-Smirnov Z & & -.052 \\
Asymp. Sig. (2-tailed) & .647 \\
\hline
\end{tabular}

a. Test distribution is Normal.

b. Calculated from data.

Sumber: Output SPSS statistics 20.0

Berdasarkan tabel di atas, dapat diketahui bahwa hasil pengolahan data menunjukan besar nilai Kolmogorov-Smirnov 0.647 dan signifikansi pada $0.796>$ 0.05 maka dapat diinterpretasikan residual terdistribusi secara normal.

\section{Uji Multikolinearitas}

\section{Coefficients $^{\mathrm{a}}$}

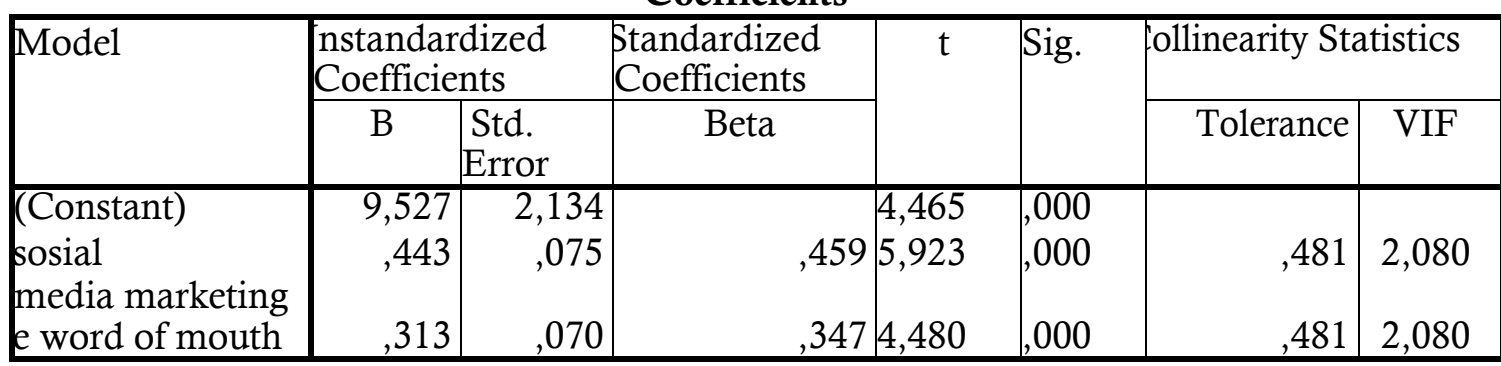

b. Dependent Variable: Y

Sumber: Output SPSS 20.0

Berdasarkan hasil tabel 50, menunjukan bahwa nilai tolerance variabel sosial media marketing dan e-word of mouth sebesar 0,481 yang berarti dua variabel tersebut memiliki nilai lebih besar dari 0,1 (nilai tolerance $>0.10$ ), sedangkan nilai Viriance Inflation Factor (VIF) variabel sosial media marketing dan e-word of mouth 2.080 yang berarti dua variabel tersebut memiliki nilai yang lebih kecil dari 10,00 (nilai VIF < 10,00). Sehingga dengan demikian dapat di interprestasikan tidak ada multikolonieritas antara variabel independen dalam model regresi. 


\section{Uji Heteroskedastisitas}

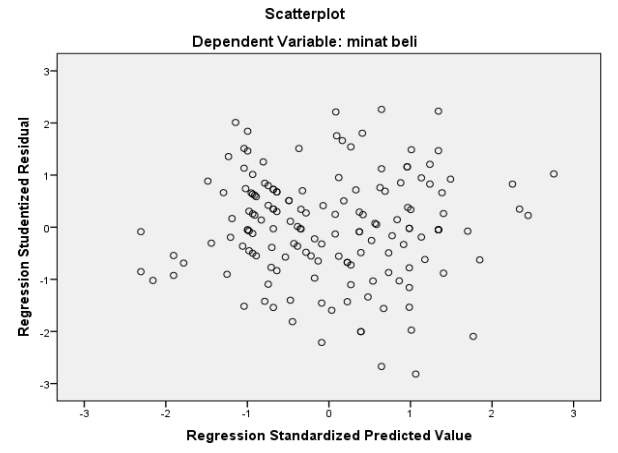

Sumber: Output SPSS statistics 20.0
Customer Buying

Decision and

Promotional Mix

Berdasarkan grafik Scatterplot terlihat bahwa tidak ada pola yang jelas dan titik- titik menyebar secara acak serta tersebar baik di atas maupun di bawah angka 0 (nol) pada sumbu Y, sehingga dapat diinterpretasikan bahwa tidak terjadi heteroskedastisitas dalam model regresi.

\section{Uji Autokorelasi}

Pada output run test terlihat bahwa nila test -0.7108 sedangkan Asymp. Sig (2tailed) adalah 0.573 untuk menyimpulkan apakah terjadi gejala autokorelasi atau tidak maka nilai test dibandingkan dengan nilai tabel atau nilai probabilitas didingkan dengan nilai alphanya. Berdasarkan output tersebut diperoleh nilai Asymp. Sig (2-tailed) sebesar $0.573>0.05$, sehingga dapat disimpulkan tidak terdapat autokorelasi.

\begin{tabular}{|c|c|}
\hline \multicolumn{2}{|c|}{ Runs Test } \\
\hline & $\begin{array}{c}\text { Unstandardized } \\
\text { Residual }\end{array}$ \\
\hline $\begin{array}{l}\text { Test Value }{ }^{\mathrm{a}} \\
\text { Cases }<\text { Test Value } \\
\text { Cases }>=\text { Test Value } \\
\text { Total Cases } \\
\text { Number of Runs } \\
\text { Z } \\
\text { Asymp. Sig. (2-tailed) }\end{array}$ & $\begin{array}{r}-.07108 \\
77 \\
78 \\
155 \\
75 \\
-.564 \\
.573\end{array}$ \\
\hline
\end{tabular}

a. Median

Sumber: Output SPSS statistics 20.0

Analisis Koefisien Determinasi $\left(R^{2}\right)$

Hasil Uji Koefisien Determinasi (Adjusted $R^{2}$ )

Model Summary

\begin{tabular}{|l|l|l|l|l|}
\hline Model & \multicolumn{1}{|c|}{ R } & R Square & djusted R Square & . Error of the Estimate \\
\hline 1 & $.749^{\mathrm{a}}$ & .561 & .555 & 2.66083 \\
\hline
\end{tabular}

a. Predictors: (Constant), e word of mouth, sosial media marketing Sumber: Output SPSS 20.0

Tabel diatas menunjukan bahwa besarnya angka Adjudted $R$ Square sebesar

0.555. besarnya persentasi kontribusi pengaruh dari Sosial Media Marketing dan E- Word Of Mouth secara bersama-sama berpengaruh terhadap Minat Beli dengan cara menghitung nilai koefisien determinasi menggunakan rumus sebagai berikut: 
Customer Buying

Decision and

Promotional Mix

242
$\mathrm{KD}=\mathrm{r}^{2} \times 100 \%$
$\mathrm{KD}=0.555 \times 100 \%$
$\mathrm{KD}=55,5 \%$

Angka tersebut menunjukan sebesar 55,5\% konstribusi sosial medi marketing dan e- word of mouth secara bersama-sama dapat mempengaruhi minat beli. Sedangkan sisanya sebesar $44,5 \%$ dipengaruhi oleh faktor-faktor lain diluar penelitian.

Uji Statistik t (Uji Regresi Secara Parsial)

Uji ini dilakukan untuk menguji variabel Sosial Media Marketing (X1) dan E-Word Of Mouth (X2) berpengaruh secara parsial terhadap variabel Minat Beli (Y) terlihat bahwa:

1. Uji hipotesis secara parsial Sosial Media Marketing memiliki pengaruh yang signifikan terhadap Minat Beli. Hal ini terlihat bahwa dari hasil perhitungant hitung sebesar 5,923 $>\mathrm{t}=1,9756$ dan nilai signifikansi $0,000<0,05$ maka $\mathrm{H} 1$ diterima.

2. Uji hipotesis secara parsial E-Word Of Mouth memiliki pengaruh yang signifikan terhadap minat beli. Hal ini terlihat bahwa dari hasil perhitungant hitung sebesar 4.480 $>\mathrm{t}=1,9756$ dan nilai signifikansi $0,005<0,05$ maka $\mathrm{H} 2$ diterima.

Uji Statistik F (Uji Koefisien Regresi Secara Silmutan)

Hasil Uji Statistik F ANOVA ${ }^{\mathrm{a}}$

\begin{tabular}{|l|l|r|r|l|l|}
\hline Model & $\begin{array}{l}\text { Sum of } \\
\text { Squares }\end{array}$ & df & $\begin{array}{r}\text { Mean } \\
\text { Square }\end{array}$ & F & Sig. \\
\hline Regression & 1375.750 & 2 & 687.875 & 97.15 & $.000^{\mathrm{b}}$ \\
Residual & 1076.160 & 152 & 7.080 & 7 & \\
Total & 2451.910 & 154 & & & \\
\hline
\end{tabular}

a. Dependent Variable: minat beli (y)

b. Predictors: (Constant), e word of mouth (x2), sosial media marketing (x1)

Sumber: Output SPSS 20.0

Berdasarkan tabel 53, dapat diketahui bahwa tingkat signifikan sebesar 0.000

$<0.05$ dengan nilai Fhitung $=97.157>\mathrm{F} 0.05(152)=3.06$, sehingga dapat diinterpretasikan bahwa Sosial Media Marketing dan E-Word Of Mouth secara simultan berpengaruh signifikan terhadap Minat Beli. Dengan demikian H3 diterima.

Analisis Koefisien Korelasi Parsial

Koefisien Korelasi Parsial Antara Sosial Media Marketing Dan Minat Beli

Correlations

\begin{tabular}{|ll|r|r|}
\hline Control Variables & $\begin{array}{l}\text { Sosial Media } \\
\text { Marketing }\end{array}$ & Minat Beli \\
\hline Sosial Media Marketing & Correlation & 1.000 & .433 \\
E Word Of & Significance (2-tailed) &. & .000 \\
& Df & 0 & 152 \\
Mouth & Correlation & .433 & 1.000 \\
Minat Beli & Significance (2-tailed) & .000 & .152 \\
& Df & \\
\hline
\end{tabular}

Sumber: Output SPSS 20.0

Nilai koefisien korelasi parsial variabel sosial media marketing (X1) dan minat belli (Y) sebesar 0.433 dengan tingkat signifikansi sebesar $0,000<0,05$, maka terdapat hubungan yang positif, kuat dan signifikan. Jika Sosial Media Marketing (X1) meningkat dengan asumsi E-Word Of Mouth (X2) tetap, maka Minat Beli (Y) akan meningkat dan sebaliknya.

\section{Koefisien Korelasi Parsial Antara E-Word Of Mouth Dan Minat Beli Correlations}




\begin{tabular}{|ll|r|r|}
\hline Control Variables & & E-Word Of Mouth & Minat Beli \\
\hline \multirow{3}{*}{ E Word Of Mouth } & Correlation & 1.000 & .342 \\
& Significance (2- & $\cdot$ & .000 \\
Sosial Media Marketing & tailed) & & \\
& Df & .342 & 152 \\
Minat Beli & Correlation & .000 & 1.000 \\
& Significance (2- & 152 & $\cdot$ \\
& tailed) & & 0 \\
\hline
\end{tabular}

Customer Buying

Decision and

Promotional Mix

Sumber: Output SPSS 20.0

Berdasarkan tabel diatas, nilai koefisien korelasi parsial variabel E-Word OfMouth (X2)

dan Minat Beli (Y) sebesar 0,342 dengan tingkat signifikansi sebesar 0,000 0,05

maka terdapat hubungan yang positif, kuat dan signifikan. Jika E- Word Of Mouth

(X2) meningkat dengan asumsi Sosial Media Marketing (X1) tetap, maka Minat Beli (Y)

akan meningkat dan sebaliknya.

Analisis Koefisien Korelasi Berganda

Hasil Analisis Koefisien Korelasi Berganda Model Summary

\begin{tabular}{|l|l|l|l|l|}
\hline Model & R & R Square & Adjusted R Square & $\begin{array}{l}\text { Std. Error of the } \\
\text { Estimate }\end{array}$ \\
\hline 1 & $.749^{\mathrm{a}}$ & .561 & .555 & 2.66083 \\
\hline
\end{tabular}

a. Predictors: (Constant), e word of mouth, sosial media marketing

Sumber: Output SPSS 20.0

Berdasarkan tabel diatas, Model summary diperoleh koefisien korelasi berganda variabel Sosial Media Marketing dan E-Word Of Mouth terhadap Minat Beli (R) = 0,749, berarti kedua variabel yaitu Sosial Media Marketing dan E-Word Of Mouth secara bersamasama mempunyai tingkat hubungan yang kuat (berada pada interval $0,61-0,80$ ) terhadap Minat Beli.

\section{PEMBAHASAN}

Sebagai hasil penelitian Sosial Media Marketing, E-Word Of Mouth terhadap Minat Beli dengan menggunakan metode statistik maka dapat di deskripsikan hasil penelitian sebagai berikut:

1. Tanggapan Responden Terkait Sosial Media Marketing (X1), E-Word Of Mouth (X2), dan Minat Beli (Y)

- Secara keseluruhan tanggapan responden terhadap variabel sosial media marketing adalah baik $(3,90 ; 5) \times 100 \%=78 \%$, karena berada diantara interval $(68.01-84,00)$.

- Secara keseluruhan tanggapan responden terhadap variabel electronic word of mouth adalah baik $(4,11 ; 5) \times 100 \%=52,2 \%$, karena berada diantara interval $(68.01-84,00)$.

- Secara keseluruhan tanggapan responden terhadap variabel Minat Beli Pada Produk Sepatu Converse adalah baik $(4,11 ; 5) \times 100 \%=52,2 \%$, karena berada diantara interval $(68.01-$ $84,00)$.

2. Hasil Analisis Regresi Linier Berganda

Berdasarkan hasil uji analisis regresi linier berganda dapat dilihat bahwa nilai konstanta sebesar 9.527 secara sistematis menyatakan bahwa jika nilai variabel X1 (sosial media marketing) dan X2 (e-word of mouth) sama dengan nol maka nilai skor Y (minat beli) adalah 9.527 Koefisien regresi variabel X1 (sosial media marketing) sebesar 0.443, yang artinya setiap X1 (sosial media marketing) meningkat sebesar 1 skor dengan asumsi variabel X2 (e-word of mouth) konstan akan menyebabkan kenaikan skor minat beli sebesar 0.443 dan sebaliknya. Koefisien regresi variabel X2 (e-word of mouth) sebesar 
Customer Buying

Decision and

Promotional Mix

244
0.313 , artinya setiap X2 (e-word of mouth) meningkat sebesar 1 skor dengan variabel X1 (sosial media marketing) konstan akan menyebabkan kenaikan skor minat beli sebesar 0.313 dan sebaliknya.

3. Hasil Analisis Koefisien Determinasi $\left(\mathrm{R}^{2}\right)$ dan Hasil Koefisien Korelasi Berganda.

Hasil analisis koefisien determinasi $\left(\mathrm{R}^{2}\right)$ sebesar 0.555 , besarnya persentasi kontribusi pengaruh dari sosial media marketing dan e-word of mouth secara bersama-sama berpengaruh terhadap minat beli dengan cara menghitung nilai koefisien determinasi dan mendapatkan hasil sebesar 55,5\% konstribusi pengaruh sosial media marketing dan e-wom secara bersama- sama dapat mempengaruhi minat beli. Sedangkan sisanya sebesar $44,5 \%$ dipengaruhi oleh faktor-faktor lain diluar penelitian.

Hasil diperoleh dari koefisien korelasi berganda variabel Sosial Media Marketing dan E-Word Of Mouth terhadap Minat Beli $(\mathrm{R})=0,749$, berarti kedua variabel yaitu Sosial Media Marketing dan E-Word Of Mouth secara bersama-sama mempunyai tingkat hubungan yang kuat (berada pada interval 0,61 -0,80) terhadap Minat Beli.

Pengaruh Sosial Media Marketing Terhadap Minat beli

Berdasarkan hasil uji t yang dilakukan, dapat diketahui Sosial Media Marketing memiliki pengaruh yang signifikan terhadap Minat Beli. Hal ini terlihat bahwa dari hasil perhitungan $t$ hitung sebesar 5,923 $>\mathrm{t}=1,9756$ dan nilai signifikansi $0,000<0,05$ maka $\mathrm{H} 1$ diterima. Hasil penelitian yang menyatakan bahwa ada pengaruh dari variable Sosial Media Marketing Terhadap Minat Beli. Sesuai dengan penelitian yang dilakukan oleh Meatry Kurniasari dan Agung Budiatmo (2018) dengan judul Pengaruh Sosial Media Marketing, Brand Awereness Terhadap Keputusan Pembelian Dengan Minat Beli Sebagai Variabel Intervening Pada J.Co Donuts \& Coffe Semarang. Menghasilkan bahwa Berdasarkan hasil analisis regresi tahap pertama bahwa variable sosial media marketing dan brand awereness menunjukan terdapat hubungan positif dengan minat beli, maka semakin besar sosial media marketing dan brand awereness akan meningkatkan minat beli. Pengaruh E-Word Of Mouth Terhadap Minat Beli

Berdasarkan hasil uji t yang dilakukan, dapat diketahui E-Word Of Mouth memiliki pengaruh yang signifikan terhadap Minat Beli. Hal ini terlihat bahwa dari hasil perhitungan $\mathrm{t}$ hitung sebesar $4.480>\mathrm{t}=1,9756$ dan nilai signifikansi $0,005<0,05$ maka $\mathrm{H} 2$ diterima. Hasil penelitian yang menyatakan bahwa ada pengaruh dari variable E-Word Of Mouth. Sesuai dengan penelitian yang dilakukan oleh Penelitian Muhammad Aries, Sunarti dan M Kholid Mawardi (2018) dengan judul Pengaruh Word Of Mouth Terhadap Minat Beli Serta Dampaknya Pada Keputusan Pembelian (Survei Pada Make Up Artist Yang Membeli dan Menggunakan Produk Kryolan di Kabupaten Bojonegoro). Menghasilkan bahwa Hasil penelitian menunjukan bahwa variable word of mouth (x) memiliki pengaruh secara langsung terhadap minat beli (Y1) dengan arah yang positif sebesar 0,650. Nilai probabilitas sebesar 0,000 $(<0,05)$, hal ini berarti bahwa ada pengaruh yang signifikan.

\section{Hasil Analisis Regresi Linier Berganda}

Berdasarkan hasil uji analisis regresi linier berganda dapat dilihat bahwa nilai konstanta sebesar 9.527 secara sistematis menyatakan bahwa jika nilai variabel $\mathrm{X}_{1}$ (sosial media marketing) dan $\mathrm{X}_{2}$ (e-word of mouth) sama dengan nol maka nilai skor $\mathrm{Y}$ (minat beli) adalah 9.527 Koefisien regresi variabel $\mathrm{X}_{1}$ (sosial media marketing) sebesar 0.443 , yang artinya setiap $\mathrm{X}_{1}$ (sosial media marketing) meningkat sebesar 1 skor dengan asumsi variabel $\mathrm{X}_{2}$ (e-word of mouth) konstan akan menyebabkan kenaikan skor minat beli sebesar 0.443 dan sebaliknya. Koefisien regresi variabel $\mathrm{X}_{2}$ (e-word of mouth) sebesar 0.313 , 
artinya setiap $\mathrm{X}_{2}$ (e-word of mouth) meningkat sebesar 1 skor dengan variabel $\mathrm{X}_{1}$ (sosial media marketing) konstan akan menyebabkan kenaikan skor minat beli sebesar 0.313 dan sebaliknya.

Customer Buying

Decision and

Promotional Mix

\section{Hasil Analisis Koefisien Determinasi $\left(\mathrm{R}^{2}\right)$ dan Hasil Koefisien Korelasi Berganda.}

Hasil analisis koefisien determinasi $\left(\mathrm{R}^{2}\right)$ sebesar 0.555 , besarnya persentasi kontribusi pengaruh dari sosial media marketing dan e-word of mouth secara bersama-sama berpengaruh terhadap minat beli dengan cara menghitung nilai koefisien determinasi dan mendapatkan hasil sebesar 55,5\% konstribusi pengaruh sosial media marketing dan e-wom secara bersama-sama dapat mempengaruhi minat beli. Sedangkan sisanya sebesar $44,5 \%$ dipengaruhi oleh faktor-faktor lain diluar penelitian. Hasil diperoleh dari koefisien korelasi berganda variabel Sosial Media Marketing dan E-Word Of Mouth terhadap Minat Beli (R) $=0,749$, berarti kedua variabel yaitu Sosial Media Marketing dan E-Word Of Mouth secara bersama-sama mempunyai tingkat hubungan yang kuat (berada pada interval 0,61 0,80) terhadap Minat Beli.

\section{PENUTUP}

Variabel dalam penelitian ini adalah Sosial Media Marketing, Electronic word of Mouth dan beli dengan tujuaPn untuk mengetahui pengaruh dari variabel Sosial Media Marketing dan Electronic word of Mouth baik secara silmutan maupun parsial. Berdasarkan hasil analisis dengan menggunakan SPSS dapat disimpulkan bahwa :

1. Sosial Media Marketing berpengaruh positif dan signifikan terhadap Minat Beli Mahasiswa FEB Universitas Prof. DR. Hamka.

2. E-Word Of Mouth berpengaruh positif dan siginifikan terhadap Minat

Beli Mahasiswa FEB Universitas Prof. DR. Hamka.

3. Sosial Media Marketing dan E-Word Of Mouth bersama-sama

berpengaruh positif dan signifikan terhadap Minat Beli Mahasiswa FEB Universitas Prof. DR. Hamka.

Dari hasil ini diharapkan dapat memberikan dampak positif kepada calon konsumen dan perussahaan seharusnya lebih memperhatikan tentang produk yang akan mereka pasarkan. Hal ini menunjukan bahwa besar kontribusi pengaruh Sosial Media Marketing dan E-Wom secara bersama-sama dapat mempengaruhi Minat Beli. Sedangkan sisanya sebesar $44,5 \%$ dipengaruhi oleh faktor-faktor lain diluar penelitian.

\section{DAFTAR PUSTAKA}

[1] Akmal Ghani Dwianto Mohammad Iqbal Rizal Alfisyahr (2018). "Analisis Dampak Pemasaran Di Media Sosial Online Terhadap Citra Merek, Minat Beli Konsumen, Dan Net Promoter Score". Administrasi Bisnis (JAB) Volume 55 No.1 Februari, Jogjakarta

[2] Citra Sugianto Putri (2016). "Pengaruh Media Sosial Terhadap Keputusan Pembelian Konsumen Cherie Melalui Minat Beli". Jurnal Manajemen dan Start-Up Bisnis Volume 1 No. 5 Desember, Surabaya

[3] Deru R. Indika, Cindy Jovita (2017) "Media Sosial Instagram Sebagai Sarana Promosi Untuk Meningkatkan Minat Beli Konsumen". Jurnal Bisnis Terapan Volume 1 No.1 Juni, Bandung

[4] Dewi Kurniawati, Nugraha Arifin (2015). "Strategi Pemasaran Melalui Media Sosial dan Minat Beli Mahasiswa". Simbolika Volume 1 No. 2 September, Sumatra Utara

[5] Firman Dwi Cahyono, Andriani Kusumawati, Srikandi Kumadji (2016) "Analisis Faktor-Faktor Pembentuk Electronic Word-Of-Mouth (Ewom) Dan Pengaruhnya Terhadap Minat Beli". Jurnal Administrasi Bisnis (JAB) Volume 37 No.1 Agustus, 
Customer Buying Decision and Promotional Mix

\section{6}

Malang

[6] Gevi Tonida Resky (2019). "Analisis Pengaruh Electronic Word Of Mouth (E-Wom) Terhadap Minat Beli Konsumen Pada Produk Tas Di Instagram Rgfashion Store". Jurnal Ilmiah Volume 3 No.2, Malang

[7] Indra Ariesta, Dinda Amanda Zuliestiana (2020). "Pengaruh Social Media Marketing Melalui Facebook Terhadap Minat Beli Produk Kartu Halo Pt. Telkomsel West - Jabodetabek". e-Proceeding of Management Volume 6 No.2 Agustus, Bandung.

[8] Lubiana Mileva Achmad Fauzi DH (2018) "Pengaruh Social Media Marketing Terhadap Keputusan Pembelian". Jurnal Administrasi Bisnis (JAB) Volume 58 No.1 Mei, Malang..

[9] Meatry Kurniasari, Agung Budiatmo (2018). "Pengaruh Social Media Marketing, Brand Awareness Terhadap Keputusan Pembelian Dengan Minat Beli Sebagai Variabel Intervening Pada J.Co Donuts \& Coffee Semarang". Diponegoro Journal Of Social And Politic. Hal 1-7.

[10] Muhammad Aries Sunarti, M. Kholid Mawardi (2018). "Pengaruh Word Of Mouth Terhadap Minat Beli Serta Dampaknya Pada Keputusan Pembelian (Survei Pada Make Up Artist Yang Membeli Dan Menggunakan Produk Kryolan Di Kabupaten Bojonegoro) " Jurnal Admnistrasi Bisnis Volume 60 No.3, Malang

[11] Muhammad Sohaib, Peng Hui and Umair Akram (2018) "Impact of eWOM and risk-taking in gender on purchase intentions: evidence from Chinese social media". Information systems and change management Volume 10 No.2, China.

[12] Nurfitriani (2016). "Pengaruh Social Media Marketingmelalui Official Account Line Alfamart Terhadap Minat Beli Konsumen". JOM-FISIP Oktober, Riau.

[13] Patria Laksamana (2018). "Impact of Social Media Marketing on Purchase Intention and Brand Loyalty: Evidence from Indonesia's Banking Industry".International Review of Management and Marketing | Volume 8 No.1, Indonesia

[14] Prayogi Ariesandy, Dinda Amanda Zuliestiana (2019). "Pengaruh Social Media Marketing Melalui Instagram Terhadap Minat Beli Konsumen Ladyfamesho". E Proceeding of Management Volume 6 No.2 Agustus, Bandung.

[15] Rosmaya Adriyati, Farida Indriani (2017). "Pengaruh Electronic Word Of Mouth Terhadap Citra Merek Dan Minat Beli Pada Produk Kosmetik Wardah". Diponegoro Journal Of Management Volume 6 No.4 Hal 1-14, Semarang.

[16] Cahyono, Firman Dwi. Kusumawati, Andraini. Kumadji, Srikandi. (2016). Analisis Faktor - Faktor Pembentuk Electronic Word of Mouth (eWOM) dan Pengaruhnya terhadap Minat Beli. Jurnal Administrasi Bisnis, 37 (1): 148-157. 